UDC 582: $542.1(575.2)(04)$

BLC 28.592.71 (5Кир)

\title{
THE SYNOPSIS OF THE GENUS PHLEUM L. (POACEAE) IN FLORA OF THE KYRGYZ REPUBLIC
}

\author{
Adilet K. Usupbaev \\ Institute for Biology, National Academy of Sciences Kyrgyz Republic, \\ Bishkek, Kyrgyz Rebublic
}

\begin{abstract}
On the base of investigation of material kept in Herbarium of flora laboratory (Institute for Biology and Pedology, National Academy of Sciences (FRU), a synopsis of the genus Phleum L. (Poaceae) in flora of Kyrgyz Republic with a key for identification of species and short citats is presented. Six species are recognized in Kyrgyz Republic (Phleum phleoides H. Karst., Phleum himalaicum Mez, Phleum paniculatum Huds., Phleum pratense L., Phleum roshevitzii Pavlov, Phleum alpinum L.). Phleumroshevitzii Pavlov newly reported for Kyrgyz Republic (Issyk-Kul Lake depression, Northern Kyrgyzstan). Maps of distribution for species growing in Kyrgyz Republic (Laskov GA., Sultanova BA., 2011) and list of studied specimens are provided. NK - Northern Kyrgyzstan (Chu Valley with adjacent northern macro-slope of Alexander Mountain Range, and the basin of Chon-Kemin River); IK - Issyk-Kul Lake depression (including northern macro-slope of TerskeiAla-Too Mountain Range, southern slope of KungeiAla-Too Mountain Range, basins of Tyup, Jergalan, and Karkyra rivers); CT - Central Tien Shan (basin of the Sary-Dzhaz River); WT - esternTien Shan (Talas and Chatkal valleys together with slopes of adjacent mountain ranges, and Ketmen-Tyube Valley); F - Cis-Ferghanian Kyrgyzstan (edges of the Fergana Valley, with adjacent macro-slopes of Chatkal Mountain Range, Fergana Mountain Range, Turkestan Mountain range, and Alai Mountain System); IT - Inner Tien Shan (the area bounded in the north by Kyrgyz Mt. Ridge, in the southwest by Fergana Mountain Range, and in the south-east by Kokshaal-Too Mountain System); A - Alai Valley (including southern macro-slope of Alai Mts. and northern macro-slope of Trans-Alai Mt. Range); EK - Entire territory of Kyrgyzstan (i. e. species is registered in all of abovementioned regions).

Kyrgyz Republic is located in the centre of Eurasia. The distance to an Indian Ocean is about $3000 \mathrm{~km}$. The total square is about $198,500 \mathrm{~km}^{2}$. Altitudes are from 410 to $7439 \mathrm{~m}$ above sea level. Over $90 \%$ of the territory is elevated above $1500 \mathrm{~m}$. About $40 \%$ of nearly uninhabitable: glaciers, permanent snow, rocks, scree, alpine desert, etc. Ca. $7 \%$ of territory is occupied by the cultural landscape: fields, settlements, roads, and industry (Atlas...1987).

Only the main literature sources are cited for species: "Flora URSS" (Ovczinnikov, 1934), "Flora of Kirghiz SSR"(Nikitina, 1950), "Conspectus florae AsiaeMediae" (Gamajunova, 1968), and also the monograph of Tzvelev NN. "Grasses of URSS" (Tzvelev, 1976).

The article contains 1 Figures, 1 key for identification of species, and 11 References.

Key words: Phleum, Poaceae, Kyrgyz Republic, Herbarium, new records.
\end{abstract}

УДК 582: $542.1(575.2)(04)$

ББК 28.592 .71 (5Кир)

\section{ОБЗОР ВИДОВ РОДА РНLЕUМ L.(РОАСЕАЕ) ВО ФЛОРЕ КЫРГЫЗСКОЙ РЕСПУБЛИКИ}

\author{
Адилет Кыдыкбекович Усупбаев \\ Институт Биологии Национальной Академии наук Кыргызской Республики, \\ г. Бишкек, Кыргызская Республика
}

Аннотация. Впервые проведена ревизия материалов гербария (FRU) БПИ НАН КРрода Phleum L.,включающий в себя 6 дикорастущихс ключом для определения видов, а также краткими номенклатурными 
цитатами. При необходимости виды снабжены примечаниями. Указаны данные по распределению видов по высотным поясам и их приуроченность к основным флороценотипам КР. Распространение видов на территории КР иллюстрируется точечными картами. Вид Phleum roshevitzii Pavlov указан впервые для КР. Обзор сопровождается иллюстрациями - фотографиями колосковых чешуй, имеющие значение для их определения.

Ключевые слова: Phleum, Роасеае, Кыргызская Республика, гербарий, новые находки.

Введение. КР расположена в центре Евразии. Расстояние до ближайшего Индийского океана - около 3 тыс. км. Общая площадь составляет 198,5 тыс. км². Амплитуда высот - от 410 до 7439 м над уровнем моря. Свыше $90 \%$ территории поднято выше 1500 м над ур. м. Около 40 \% почти непригодно для жизни: это ледники, вечные снега, скалы, осыпи, высокогорные пустыни и т. п. Около 7 \% территории заняты культурным ландшафтом: полями и населенными пунктами, дорогами и промышленными объектами [2].

Дикорастущие злаки КР - это основной компонент пастбищ, как кормовые растения, хорошо поедаемые всеми видами сельскохозяйственных животных [6;9; 13$]$.

Значение злаков в сложении растительности КР довольно велико, поскольку они здесь встречаются почти везде и часто произрастают массово на больших площадях. Особую группу составляют редкие и эндемичные виды растений, представляющие большую ценность как генофонд, зачастую сокращающиеся (численно и по площадям произрастания) вследствие антропогенного пресса. Нами проведены разносторонние исследования злаков КР с учетом его современного состояния, разработаны научно обоснованные приемы рационального природопользования целенаправленных на сохранение и восстановление естественной растительности [7; 14].

Семейство злаковых является одним из крупнейших семейств однодольных и их таксономическое изучение еще не завершено. Особенно это касается многих территорий Азии, где не до конца выявлен видовой состав семейства и продолжают описываться не только виды, но и роды злаков [1; 5; 7; 14; 17-20].

Согласно Н.Н. Цвелеву [15], около 20 видов рода Phleum L., распространены почти во всех внетропических странах обоих полушарий, но главным образом в странах Средиземноморья. 9 видов встречается в бывшем CССР, а на территории КР - 5 видов.
Во «Флоре Киргизской ССР» [9] род Phleum L. был обработан Е.В. Никитиной. Для территории КР она приводит 5 видов. Сведения, приведенные в этом издании, заметно устарели, так как за годы, прошедшие со времени публикации этой работы, был накоплен большой фактический материал по данному роду, требующий критической ревизии. Поэтому нами проведена ревизия рода Phleum L. во флоре КР.

Материалы и методы исследований. Настоящая работа основана на материалах гербария Биолого-почвенного института Национальной Академии наук KP (FRU), а так же гербарий семейства мятликовых, собранных нами в разных ботанико-географических районах КР начиная с 2010 по 2017 годы. Всего злаков в FRU около 12,3 тыс. листов, 325 видов из 80 родов, из них киргизской флоры 12,2 тыс. листов. Для уточнения определения некоторых чужеродных, заносных видов нами были просмотрены гербарные материалы, хранящиеся в Институте ботаники и фитоинтродукции Республики Казахстан (АА).

В процессе определения использовались сводки: [3; 4; 8; 9; 11; 12].В работе нами использовался морфолого-географический метод. На фотографиях изображены органы растений, имеющие значение для их определения, с указанием размеров (см. рис. 1). Составлен определительный ключ для видов, встречающихся на территории Кыргызстана.

Для видов, впервые приводимых для территории республики, цитируются этикетки. Римскими цифрами, указывается месяцы цветения и плодоношения. При необходимости виды снабжены примечаниями. Данные из протолога и общее распространение видов приводятся по Н.Н. Цвелева [16].

Карты-схемы распространения видов выполнены точечным методом. Точки поставлены с учетом генерализации отдельных местонахождений. Распространение видов на территории Кыргызской Республики приводиться 
по ботанико-географическим районам, согласно Г.А. Лазьков, Б.А. Султанова [6]. СК - Северный Кыргызстан (Чуйская долина с прилегающим северным макросклоном хребта Киргизский Ала-Тоо и бассейн реки Чон-Кемин); ПИ - Прииссыккулье (озерная котловина, включая северный макросклон хребта Терскей Ала-Тоо, южный склон Кунгей Ала-Тоо, бассейны рек Тюп, Джергалан и Каркыра); ЦТ Центральный Тянь-Шань (бассейн реки СарыДжаз); ЗТ - Западный Тянь-Шань (включает Таласскую и Чаткальскую долины, с прилегающими хребтами, и Кетмень-Тюбинскую котловину); ПФ - Приферганские районы (включая прилежащие южные склоны Чаткальского и Ферганского хребтов, и северные склоны Алайского и Туркестанского хребтов); ВТ Внутренний Тянь-Шань (район, ограниченный на западе Ферганским хребтом, на севере Киргизским и Терскей Ала-Тоо, на юго-востоке - хребтом Кокшаал-Тоо); А - Алайская долина (включая южные склоны Алайского и северные склоны Заалайского хребтов); ВК весь Кыргызстан (если вид отмечен во всех без исключения вышеприведенных выделах).

При описании поясного распределения и флороценотической приуроченности, после указания пояса (поясов), перечислены основ- ные флороценотипы КР и их (в скобках) формации или растительные группировки, к которым приурочен данный вид.

Результаты исследования и обсуждение. В результате исследования составлен конспект видов рода, встречающихся на территории КР. Для каждого вида цитируются типовые образцы или данные протолога о классическом местонахождении, а так же только те литературные источники,которые содержат информацию о распространении видов рода Phleum L. на территории КР: «Флоpa СССР» [11], «Флора Киргизской ССР» [9], «Определитель растений Средней Азии» [8], а также монография Н.Н. Цвелева «Злаки СССР» [16]. Все вышеперечисленные сводки были основаны на обработке материалов по семейству мятликовых флоры КР, хранящихся всего лишь в одном гербарии - Ботанического института им. В.Л. Комарова РАН (LE).

До сих пор семейство злаковых в крупнейшем Гербарии республики - БПИ НАН KP (FRU) не подверглось ревизии. Первые коллекции Гербария (FRU) формировались в 30-х годах, после организации И.В. Выходцевым и Е.В. Никитиной небольшого коллектива, изучавшего пастбища и сенокосы Киргизии $[10 ; 16]$.

\section{Ключ для определения видов}

1. Веточки колосовидных метелок по всей длине сросшиеся с осью метелки, оставляя свободными лишь очень короткие (до 0,5 мм дл.) ножки каждого колоска ..2.

+ Веточки колосовидных метелок короткие (1-12 мм дл.), но не сросшиеся с осью метелки и несущие более 1 колоска .....................................4.

2. Ости колосковых чешуй менее чем в 2 раза короче самих чешуй, часто почти равные им по длине ..................................... . P. alpinum.

+ ости колосковых чешуй в $2-3,5$ раза короче самих чешуй ..................................3.

3. Основание стебля луковицеобразно утолщено; стебли обычно одиночные 5. P. roshevitzii.

+ Основание стебля без луковицеобразного утолщения; растения образуют многостебельные дерновины .................................4. P. pratense.

4. Многолетние растения ......................................... P. phleoides.

+ Однолетние растения ........................................................5.

5. Колоски продолговато-клиновидные; колосковые чешуи в верхней части заметно вздутые и внезапно переходящие в острие, по килям без ресничек или с ресничками до 0,5 мм длины

+ Колоски продолговатые или эллиптические; колосковые чешуив верхней части не вздутые и более постепенно переходящие в острие, по килям с ресничками более 0,5 мм длины 


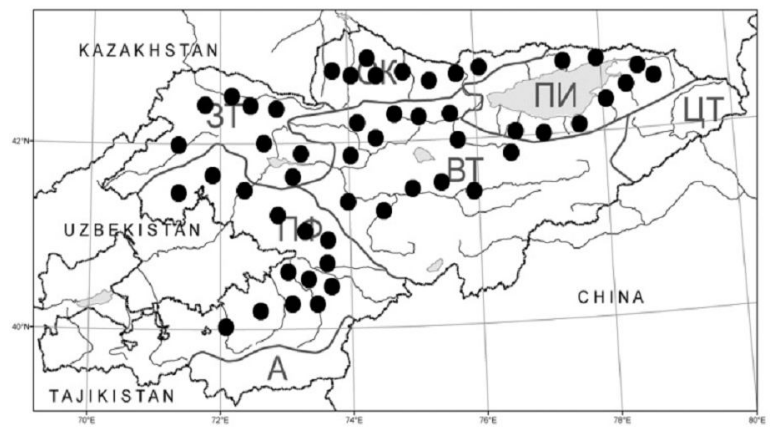

1. Phleum phleoides

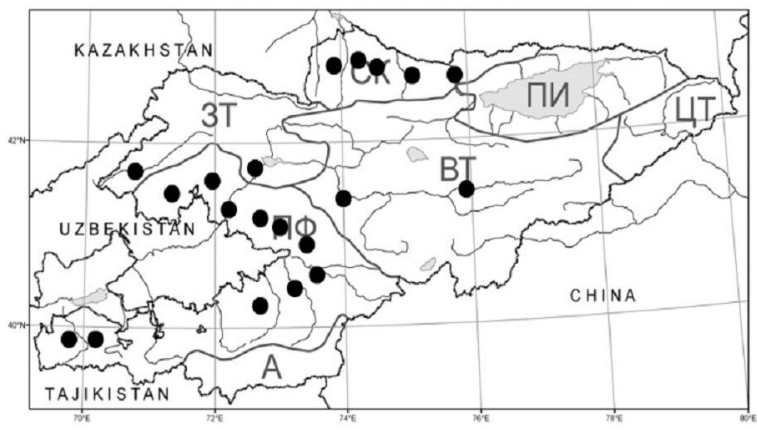

3. Phleum paniculatum

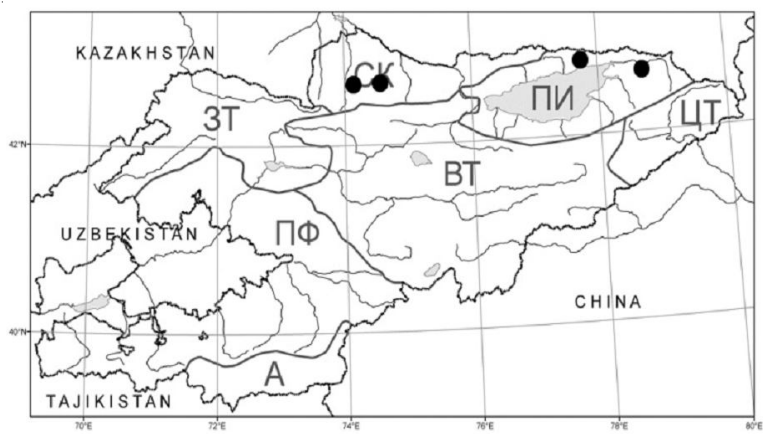

5. Phleum roshevitzii

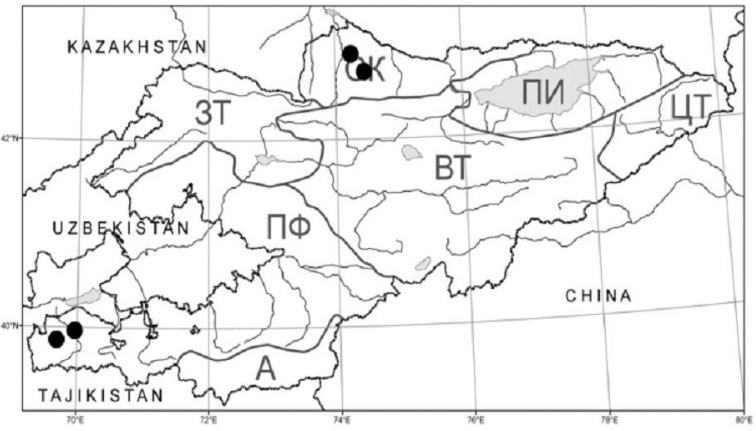

2. Phleum himalaicum

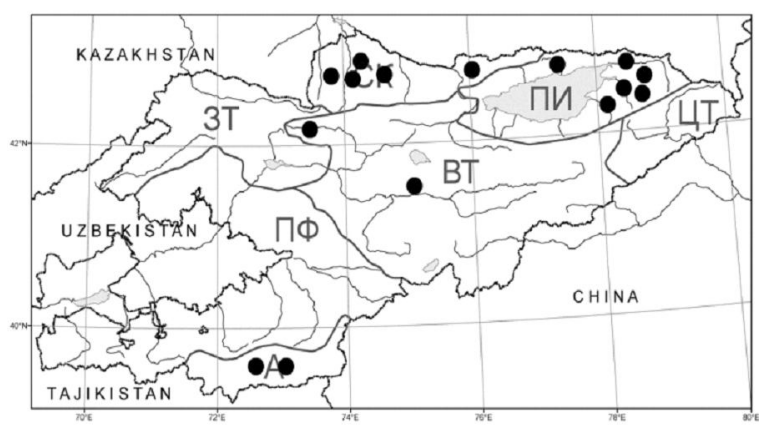

4. Phleum pretense

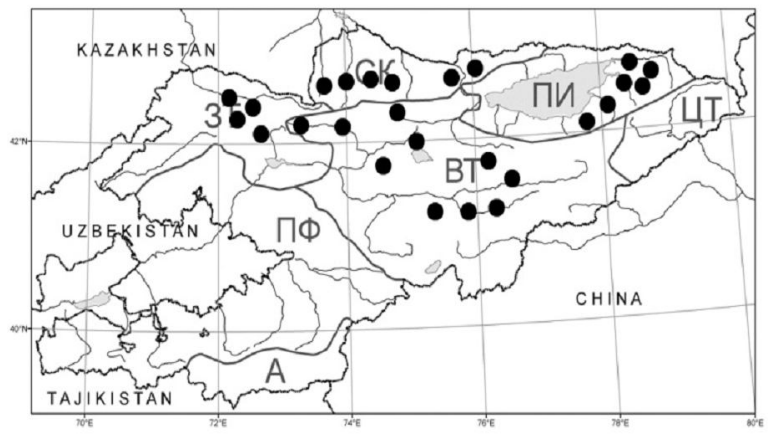

6. Phleum alpinum

Рис. 1. Карты распространения видов рода Phleum L. в Кыргызской Республике

Впервые на основе большого оригинального материала проведен в известность полный видовой состав флоры рода Phleum L., насчитывающий 6 естественных видов в пределах КР. Флора дополнена одним видом Phleumroshevitzii Pavlov, ранее не отмеченными для территории КР (рис. 2).

В статье включены только те виды, которые растут в административных границах КР, а так же только дикорастущие виды. Культивируемые растения здесь не представлены.

Изучение высотного распределения видов выявило, что один вид Phleumalpinum распространен в альпийском поясе гор (3200-4000 м над ур. м), а остальные 5 видов произрастают от пояса долин низкогорий и предгорий до среднего пояса гор (800-2000 м над ур. м).

Подрод 1. CHILOCHLOA (Beauv.) Peterm.

\section{Се ки и я 1. Chilochloa.}

1. P. phleoides H. Karst. 1881, Deut. Fl. (Karsten) 374; П. Овчинников, 1934, во Фл. СССР, 2: 131, табл. 9, рис. 6; Е. Никитина, 1950, во Фл. Кирг. ССР. 2: 70, табл. 12, рис. 2; М. Набиев, 1968, в Опред. раст. Ср. Азии, 1:91.Phleum phleoides subsp. phleoides (H. Karst.) Tzvel., 1976, Злаки СССР, 364. - Т. степная.

V-VII. Пояс долин низкогорий и предгорий, средний пояс гор (800-2000 м над ур. м); 
степи (мелкодерновинные, богато-разнотравно-злаковые), лугостепи (разнотравно-злаковые), кустарники (ксерофитные листопадные, полидоминантные), полусаванны (крупнотравные), вдоль дорог.

Распространение. Ï КР (рис. 1, карта 1): СК, ПИ, ЗТ, ПФ, ВТ. Ї Общее: Средн. Азия (ТШ, Арало-Касп., Прибалх., Джунг.-Тарб., Сырдар., Гисс.-Дарв.), Кавк., Зап. Сиб., Вост. Сиб., Дальн. Вост., Сканд., Атл. Евр., Средн. Евр., Вост. Евр., Средиз., Малоаз., Иран, Джунг.-Кашг., Монг., Яп.Кит., Южноаз. Описан из Европы.

Се ки и я 2. Achnodon (Link) Griseb.

2. P. himalaicum Mez, 1921, Repert. Spec. Nov. Regni Veg. 17: 293; Н. Цвелев, 1976, Злаки CCCP, 365.- Phleum graecum auct. non Boiss. et Heldr:: П. Овчинников, 1934, во Фл. СССР, 2: 130, табл. 9, рис. 5; Е. Никитина, 1967, во Фл. Кирг. ССР. доп. 1: 24; М. Набиев, 1968, в Опред. раст. Ср. Азии, 1: 91. - Т. гималайская.

V-VII.Пояс долин низкогорий и предгорий, средний пояс гор (800-2000 м над ур. м); перофильные группировки, галечники.

Распространение. Ï КР (рис. 1, карта 2): СК, ПФ. Ї Общее:Средн. Азия (ТШ зап., Гисс.Дарв.), Иран, Гим. Описан с Гималайских гор.

3. P. paniculatum Huds. 1762, Fl. Angl. (Hudson) 23; П. Овчинников, 1934, во Фл. СССР, $2: 130$, табл. 9, рис. 4; Е. Никитина, 1950, во Фл. Кирг. ССР. 2: 69, табл. 12, рис. 1; М. Набиев, 1968, в Опред. раст. Ср. Азии, 1: 91; Н. Цвелев, 1976, Злаки СССР, 366. - Т. метельчатая.

IV-VII. Пояс долин низкогорий и предгорий, средний пояс гор (800-2000 м над ур. м); леса (еловые, пихтовые, арчевые, стланниковые арчевники, тугаи), кустарники (полидоминантные), луга (разнотравные), полусаванны (крупнотравные), петрофильные группировки (каменистые осыпи, щебнистые осыпи, осыпи, скалы) в колючеподушечниках (ксерофильные), вдоль дорог, сельхоз поля.

Распространение. Ï КР (рис. 1, карта 3): СК, ЗТ, ПФ, ВТ. Ï Общее: Средн. Азия (ТШ, Прибалх., Джунг.-Тарб., Кызылкум, Сырдар., Амудар., Гисс.-Дарв., Туркм.), Кавк., Атл. Евр., Вост. Евр., Средиз., Малоаз., Иран, Гим. Описан из Великобритании.

\section{Подрод 2. PHLEUM.}

4. P. pratense L. 1753, Sp. Pl. 1: 59; П. Овчинников, 1934, во Фл. СССР, 2: 132, табл. 9 , рис. 10; Е. Никитина, 1950, во Фл. Кирг. ССР. 2: 70 , табл. 12 , рис. 3 , табл. 13 , рис. 5 ; М. Набиев, 1968, в Опред. раст. Ср. Азии, 1: 92. Phleum pratense subsp. pratense (L.) Tzvel., 1976, Злаки СССР, 366, табл. 6, рис. 4. - Т. луговая.

VI-VIII.Пояс долин низкогорий и предгорий, средний пояс гор (800-2000 м над ур. м); леса (еловые, арчевые, стланниковые арчевники, тугаи), кустарники (полидоминантные), лугостепи (разнотравнозлаковые), на лугах (разнотравные), вдоль дорог, сельхоз поля.

Распространение. Ï КР (рис. 1, карта 4): СК, ПИ, ВТ, А. Ї Общее: Средн. Азия (ТШзанос, Прибалх., Джунг.-Тарб., Сырдар., Гисс.Дарв.), Кавк., Зап. Сиб., Вост. Сиб., Дальн. Вост., Сканд., Атл. Евр., Средн. Евр., Вост. Евр., Средиз., Малоаз. Описан из Европы («InEuropaeversurisetpratis»).

5. P. roshevitzii Pavlov, 1932, Изв. Бот. сада АН СССР, 30: 744. - Phleum pratense subsp. roshevitzii (Pavl.) Tzvel., 1976, Злаки CССР, 367. - Т. Рожевица.

VI-VII. Пояс долин низкогорий и предгорий, средний пояс гор (800-2000 м над ур. м); луга (пойменные, высокотравные, разнотравные), лугостепи (разнотравно-злаковые), галечники, сель-хоз поля.

Распространение. Ï КР (рис. 1, карта 5): СК, ПИ. Ï Общее: Средн. Азия (ТШ зап., ТШ сев., Прибалх., Сырдар., Гисс. Дарв.). Описан с гор Каратау. Субэндемик.

Примечание. Новый вид для флоры КР. В гербарии образцы этого вида не были определены.

Изученные образцы. Иссык-Кульская область, Тонский район, станция «Каркыра», окрестности, лугостепь, 20 VII 1983, Айдарова Р.; Киргизский хребет, урочище ЧункурЧак, ложбинка, 14 VIII 1968, Молдояров.

6. P. alpinum L. 1753, Sp. Pl. 1: 59; П. Овчинников, 1934, во Фл. СССР, 2: 135, табл. 9, рис. 11 ; Е. Никитина, 1950, во Фл. Кирг. ССР. 2 : 71, табл. 12, рис. 4; М. Набиев, 1968, в Опред. раст. Ср. Азии, 1: 92; Н. Цвелев, 1976, Злаки СССР, 367. - Т. альпийская.

VI-VIII. Альпийский пояс гор (3200-4000 м над ур. м); луга (пойменные, разнотравные, криофитные низкотравные), петрофильные группировки (каменисто-щебнистые осыпи, 


\section{БИОЛОГИЯ И БИОТЕХНОЛОГИЯ}

скалы) подушечники (криоксерофильные), болота, берега рек, озер и водоемов, галечники.

Распространение. Ï КР (рис. 1, карта 6): СК, ПИ, ЗТ, ВТ. Ї Общее: Средн. Азия (ТШ, Джунг.-Тарб., Гисс.-Дарв.), Кавк., Зап. Сиб., Вост. Сиб., Дальн. Вост., Сканд., Атл. Евр., Средн. Евр., Вост. Евр., Средиз., Малоаз., Иран, Гим., Джунг.-Кашг., Монг., Яп.-Кит.,
Южноаз., Сев. Амер., Южн. Амер. Описан с гор Европы («InAlpibus»).

На рисунке 2 показаны иллюстрации фотографии колосковых чешуй видов рода Phleum L., распространенных на территории КР.

На рисунке 3 показан вид Phleum roshevitzii Pavlov, ранее не отмеченный для территории КР.
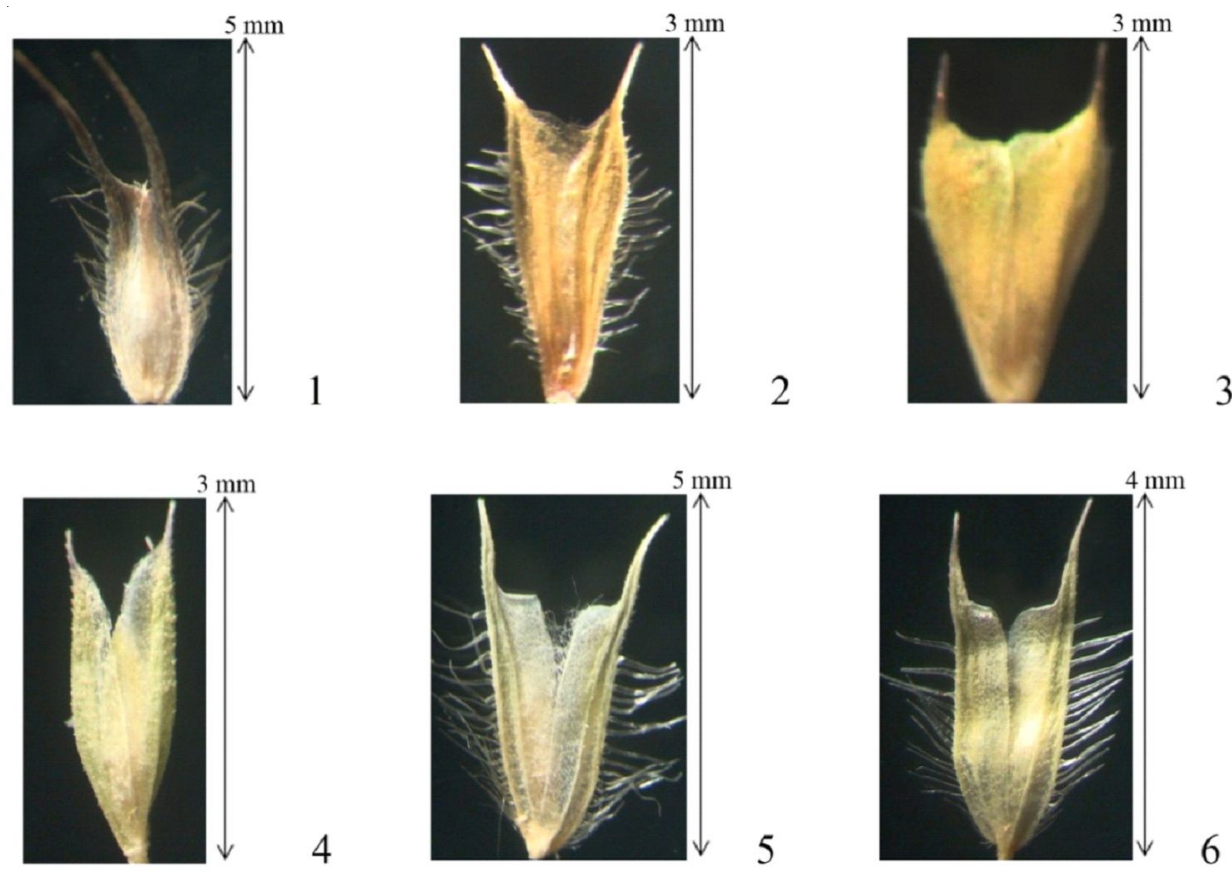

Рис. 2. Колосковые чешуи:

1 - Phleum alpinum; 2 - Phleum himalaicum; 3 -Phleum paniculatum; 4 -Phleum phleoides; 5 -Phleum pratense; 6 - Phleum roshevitzii

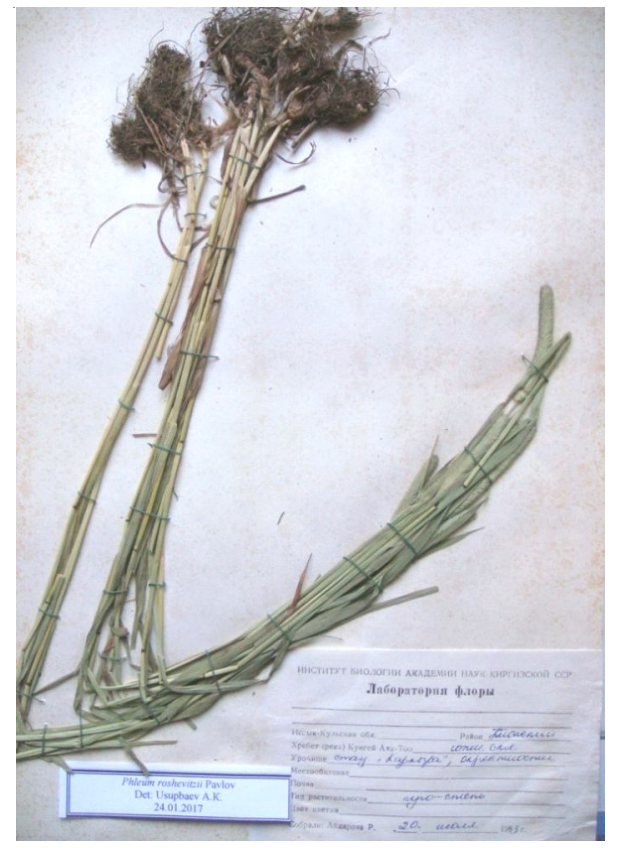

Рис. 3. Гербарий Phleum roshevitzii Pavlov (FRU) 
Заключение. В результате исследования видов рода Phleum L. (Роасеае) установлено, что флора изученной нами территории насчитывает 6 природных видов. Составлены ключ для определения и конспект рода. Изучение высотного распределения видов выявило от пояса долин низкогорий и предгорий до среднего пояса гор произрастают следующие виды: Phleumphleoides, P. himalaicum, P. paniculatum, $P$. pratense, $P$. roshevitzii. И один вид Phleumalpinum распространен в альпийском поясе гор. Вид Phleumroshevitzii Pavlov указан впервые для КР.

\section{СПИСОК ЛИТЕРАТУРЫ}

1. Алексеев, Е. Б. Род Овсяница (Festuca L.) в Средней Азии / Е. Б. Алексеев // Новости систематики высших растений. - 1979. - Т. 15. - С. 23-68.

2. Атлас Киргизской ССР. Т. 1. Природные условия и ресурсы. - М. : ГУКК, 1987. - 157 с.

3. Гамаюнова, А. П. Phleum L. / А. П. Гамаюнова // Флора Казахской ССР, Т. І. - Алма-Ата : Изд-во АН Каз. ССР, 1956. - С. 167-170.

4. Дробов, В. П. Phleum L. / В. П. Дробов // Флора Узбекской ССР, Т. I,-- Ташкент : Изд-во АН Уз. ССР, 1941.- С. 194-196.

5. Лазьков, Г. А. Новые виды родов Festuca L. (Poaceae), Phlomoides Moench (Lamiaceae), Primula L. (Primulaceae) Acantholtmon Botss. (Limoniaceae) из Кыргызстана / Г. А. Лазьков // Новости систематики высших растений. -2004. - Т. 36. - С. 28-39.

6. Лазьков, Г. А. Кадастр флоры Кыргызстана: сосудистые растения / Г. А. Лазьков, Б. А. Султанова // Norrlinia. - Т. 24. - 2011. - C. 1-166.

7. Лазьков, Г. А. Обзор рода Melica L. (Poaceae) во флоре Кыргызской Республики / Г. А. Лазьков, А. К. Усупбаев // Новости систематики высших растений. - 2017. - Т. 48. - С. 26-33.

8. Набиев, М. М. Phleum L. / М. М. Набиев // Определитель растений Средней Азии, Т. I. - Ташкент, 1968. - С. 90-92.

9. Никитина, Е. В. Phleum L. / Е. В. Никитина // Флора Киргизской ССР, Т. II. - Фрунзе, 1950. C. $69-70$.

10. Никитина, Е. В. Флора и растительность пастбищ и сенокосов хребта Киргизский Ала-Тоо /Е. В. Никитина. -Фрунзе : Илим, 1962. - 283 с.

11. Овчинников, П. Н. Phleum L. / П. Н. Овчинников // Флора СССР, Т. ІІ. - М. ; Л., 1934. - С. 127-129.

12. Овчинников, П. Н. Phleum L. / П. Н. Овчинников // Флора Таджикской ССР, Т. І. - Душанбе, 1957. - С. 396-401.
13. Содомбеков, И. С. Овсяница бороздчатая / И. С. Содомбеков-Бишкек, 1997. - 71 с.

14. Усупбаев, А. К. О двух видах рода $P o a$ L. (Роасеае) из Кыргызской Республики / А. К. Усупбаев // Доклады НАН КР. - 2017. - № 2. Ї С. 37-42.

15. Цвелев, Н. Н. Злаки СССР / Н. Н. Цвелев Л., 1976. $-788 \mathrm{c}$.

16. Цеканов, А. С. Эколого-биологические основы улучшения пастбищ высокогорий Внутреннего Тянь-Шаня / А. С. Цеканов. - Фрунзе : Илим, 1979. $-232 \mathrm{c}$.

17. Nobis, M. Remarks on the taxonomy and nomenclature of the Stipatianschanica complex (Poaceae), on the base of anewrecord or the ora of Tajikistan (central Asia) / M. Nobis // Nordic Journal of Botany - Vol. 29. - P. 194-199.

18. Nobis, M. Stipanarynica sp. nov. (Poaceae) from the western Tian-Shan Mountains / M. Nobis // Nordic Journal of Botany. - 2012. Vol. 30. - P. 70-76.

19. Zhang, Z. S. Ptilagrostis contracta (Stipeae, Poaceae), a New Species Endemic to Qinghai-Tibet Plateau / Z. S. Zhang, L. L. Li, W. L. Chen // PLoSONE. -2017. - Vol. 12 (1). - e0166603. - DOI: 10.1371/journal.

20. Parolly, G. Oreopoa gen. novum, two other new grasses and further remarkable records from Turkey / G. Parolly, H. Scholz // Botanic Garden and Botanical Museum Berlin (BGBM). Willdenowia. 2004. - Vol. 34, № 1. - P. 145-158.

\section{REFERENCES}

1. Alekseev E.B. Rod Ovsyanica (Festuca L.) v SredneyAzii [The Genus Festuca L. in Central Asia]. Novosti sistematiki vysshyh rasteniy [Atlas of the Kirghiz SSR] I. Prirodnye usloviya i resursy. Moscow, GUKK, 1987, vol. 15. $157 \mathrm{p}$.

2. Atlas Kirgizskoj SSR, Vol. I. Prirodnye uslovija i resursy [Atlas of the Kirghiz SSR]. Moscow, GUKK, 1987. $157 \mathrm{p}$.

3. Gamayunova, A.P. Phleum L. Flora Kazahskoj SSR [Flora of Kazak SSR]. Alma-Ata, Izdvo AN Kaz. SSR, 1956, vol. 1, pp. 167-170.

4. Drobov V.P. Phleum L. Flora Uzbekskoy SSR [Flora of Uzbek SSR]. Tashkent, Izd-vo AN Uz. SSR, 1941, vol. I, pp. 194-196.

5. Laz'kov, G.A. Novye vidy rodov Festuca L. (Poaceae), Phlomoides Moench (Lamiaceae), Primula L. (Primulaceae) Acantholtmon Botss. (Limoniaceae) iz Kyrgyzstana [The new species of genus Festuca L. (Poaceae), Phlomoides Moench (Lamiaceae), Primula L. (Primulaceae) Acantholtmon Botss. (Limoniaceae) from Kyrgyzstan] // Novosti sistematiki vysshyh rasteniy, 2004, vol. 35, pp. 28-39. 
6. Laz'kov G.A., Sultanova B.A. Kadastr flory Kyrgyzstana: sosudistye rasteniya [The Synopsis of the Genus Melica L. (Poaceae) in Flora of Kyrgyz Republic]. Norrlinia. 2011, vol. 24.166 p.

7. Laz'kov G.A., Usupbaev A.K. Obzor roda Melica L. (Poaceae) vo flore Kyrgyzskoy Respubliki [Conspectus Florae AsiaeMediae]. Novosti sistematiki vysshyh rasteniy, 2017, vol. 48, pp. 26-33.

8. Nabiev M.M. Phleum L. Opredelitel' rasteniy SredneyAzii. Tashkent, 1968, vol. I, p. 90-92.

9. Nikitina E.V. Phleum L. Flora Kirgizskoj SSR [Flora of Kirghiz SSR], Frunze, 1950, vol. II, p. 69-70.

10. Nikitina E.V. Flora i rastitel'nost' pastbishh i senokosov hrebta Kirgizskiy Ala-Too [Flora and Vegetation of Pastures and Hayfields of the Kyrgyz Ala-Too Range]. Frunze, Ilim, 1962. 283 p.

11. Ovchinnikov, P.N. Phleum L. Flora SSSR [Flora URSS]. Moscow, Leningrad, 1934, vol. II, pp. 127-129.

12. Ovchinnikov P.N. Phleum L. Flora Tadzhikskoj SSR [Flora of Tadshik SSR]. Dushanbe, 1957, vol. I, pp. 396-401.

13. Sodombekov I.S. Ovsyanica borozdchataya [Festu cavalesiaca Rchb]. Bishkek, 1997. 71 p.

14. Usupbaev, A.K. O dvuh vidah roda Poa L. (Poaceae) iz Kyrgyzskoy Respubliki [About Two Species of the Genus Poa L. (Poaceae) in Flora of Kyrgyz Republic]. Doklady NAN KR, 2017, vol. 2 Ï, pp. 37-42.

15. Tsvelev N.N. Zlaki SSSR [Grasses of URSS]. Leningrad, $1976.788 \mathrm{p}$.

16. Tsekanov A.S. Ekologo-biologicheskie osnovy uluchsheniya pastbishh vysokogoriy Vnutrennego Tyan'-Shanya [Ecological and Biological Basis for Improving the Pastures of the Highlands of the Inner Tien Shan]. Frunze, Ilim, 1979. 232 p.

17. Nobis M. Remarks on the taxonomy and nomenclature of the Stipatianschanica complex (Poaceae), on the base of anewrecord or the ora of Tayikistan (central Asia). Nordic Journal of Botany, vol. 29, pp. 194-199.

18. Nobis M. Stipanarynica sp. nov. (Poaceae) from the western Tian-Shan Mountains. Nordic Journal of Botany, 2012, vol. 30, pp. 70-76.

19. Zhang Z.S., Li L.L., Chen W.L. Ptilagrostis contracta (Stipeae, Poaceae), a new species endemic to Qinghai-Tibet Plateau. PLoSONE, 2017, vol. 12 (1), e0166603. DOI: 10.1371/journal.

20. Parolly G., Scholz H. Oreopoa gen. novum, two other new grasses and further remarkable records from Turkey. Botanic Garden and Botanical Museum Berlin (BGBM). Willdenowia, 2004, vol. 34 (1), pp. 145-158.

\section{Information about the Author}

Adilet K. Usupbaev, Candidate of Sciences (Biology), Institute for Biology, National Academy of Sciences of Kyrgyz Republic, Prosp. Chuy, 265, 720071 Bishkek, Kyrgyz Rebublic, adilet.usupbaev@mail.ru.

\section{Информация об авторе}

Адилет Кыдыкбекович Усупбаев, кандидат биологических наук, Институт Биологии Национальной Академии наук Кыргызской Республики, просп. Чуй, 265, 720071 г. Бишкек, Кыргызская Республика, adilet.usupbaev@mail.ru. 